\title{
TELEOLOGI HUKUM PERATURAN WALIKOTA SURABAYA NOMOR 1 TAHUN 2017 TENTANG PENYELENGGARAAN HARI BEBAS KENDARAAN BERMOTOR \\ Tomy Michael
}

Dosen Fakultas Hukum Universitas 17 Agustus 1945 Surabaya

tomy@untag-sby.ac.id

\begin{abstract}
Abstrak
Paradigma hukum dalam suatu bidang memiliki definisi yang berbeda-beda. Pembagian ilmu hukum ini hanya terkait peminatan dari seseorang yang belajar ilmu hukum. paradigma dalam konsiderans Peraturan Walikota Surabaya Nomor 1 Tahun 2017 tentang Penyelenggaraan Hari Bebas Kendaraan Bermotor (Perwali Surabaya No. 1-2017), termaktub landasan filosofisnya yaitu "bahwa sebagai upaya mengurangi dan mengendalikan pencemaran udara di wilayah Kota Surabaya yang disebabkan oleh emisi gas buang dari kendaraan bermotor serta dalam rangka mewujudkan perilaku sadar lingkungan, telah diatur pembatasan penggunaan kendaraan bermotor pada ruas jalan dan waktu tertentu berdasarkan Peraturan Walikota Surabaya Nomor 74 Tahun 2013 tentang Penyelenggaraan Hari Bebas Kendaraan Bermotor sebagaimana telah diubah dengan Peraturan Walikota Nomor 24 Tahun 2014". Mengurangi dan mengendalikan pencemaran udara di wilayah Kota Surabaya dengan mengadakan hari bebas kendaraan bermotor tidak selaras dengan tujuan hukum yaitu keadilan hukum. Keadilan hukum tidak dapat berlaku secara kaku. Keadilan hukum akan selalu berubah ketika negara menerapkan kebijakan berbeda dalam menjalankan pemerintahannya. Kesimpulan yang diperoleh dalam Perwali Surabaya No. 1-2017 tidak memiliki teleologi hukum terkait keadilan hukum. Eksistensi Perwali Surabaya No. 1-2017 hanya memberikan manfaat bagi sebagian kecil masyarakat tanpa memperhatikan kebutuhan masyarakat lainnya. Saran yang dapat diambil yaitu ketika ada peraturan perundang-undangan terkait hari bebas kendaraan bermotor maka alternatif jalan harus mendapat perhatian utama agar paradigma hukum benar-benar tercipta yang membawa konsekuensi bahwa peraturan perundang-undangan tersebut berjalan optimal.

Kata kunci: hari bebas kendaraan bermotor, keadilan hukum, teleologi hukum, paradigma hukum
\end{abstract}

\section{A. Pendahuluan}

Di dalam negara hukum, terdapat apa yang disebut paradigma hukum. Para ilmuwan akan menjelaskan dan mengembangkan paradigma dalam usaha untuk mempertanggungjawabkan dan menjabarkan perilaku beberapa aspek yang relevan dengan dunia nyata ini. ${ }^{1}$ Paradigma hukum dalam suatu negara khususnya dalam suatu kelompok tertentu akan menimbulkan berbagai jenis paradigma terhadap suatu objek hukum sehingga dalam memahaminya dapat dilihat dari berbagai sudut pandang. Berbagai jenis paradigma hukum ini haruslah dapat dipertanggungjawabkan dan dapat dipahami oleh kelompok lainnya melalui penafsiran hukum. ${ }^{2}$ Paradigma hukum dalam suatu bidang memiliki definisi yang berbeda-beda. Bidang yang dimaksud ini yaitu pembagian ilmu hukum walaupun ilmu hukum itu sui generis. Pembagian ilmu hukum ini hanya terkait peminatan dari seseorang yang belajar ilmu hukum.

Berawal dari pemahaman itu, penulis ingin mengkaji paradigma dalam konsiderans Peraturan Walikota Surabaya Nomor 1 Tahun 2017 tentang Penyelenggaraan Hari Bebas

\footnotetext{
${ }^{1}$ H R Otje Salman dan Anthon F Susanto, Teori Hukum, 2013, Bandung, Refika Aditama, h. 68.

${ }^{2}$ Makna paradigma hukum juga selaras dengan hakikat solidaritas yang berasal dari bahasa Perancis "Solidaire". Solidaritas berarti berpaut bersama, setia kawan, rasa bersatu dalam kepentingan, kehendak dan perbuatan. Dari sudut lain masyarakat dibentuk demi kesejahteraan semua anggotanya. Satu untuk semua, semua untuk satu. Demikian persatuan diperkuat dan kepribadian setiap individu dapat berkembang karena tujuan solidarisme adalah kesejahteraan umum, lebih lanjut dalam John Tondowidjojo, Hadiah Terbesar Umat Manusia, Tahun II/Edisi 21/XII-2016 Surabaya, Gereja Katolik Kristus Raja.
} 
Kendaraan Bermotor (Perwali Surabaya No. 1-2017)3, termaktub landasan filosofisnya yaitu "bahwa sebagai upaya mengurangi dan mengendalikan pencemaran udara di wilayah Kota Surabaya yang disebabkan oleh emisi gas buang dari kendaraan bermotor serta dalam rangka mewujudkan perilaku sadar lingkungan, telah diatur pembatasan penggunaan kendaraan bermotor pada ruas jalan dan waktu tertentu berdasarkan Peraturan Walikota Surabaya Nomor 74 Tahun 2013 tentang Penyelenggaraan Hari Bebas Kendaraan Bermotor sebagaimana telah diubah dengan Peraturan Walikota Nomor 24 Tahun 2014".

Landasan filosofis tersebut dapat dimaknai sebagai landasan sosiologi karena apabila mengacu pada makna landasan filosofis maka hal tersebut adalah salah. Landasan filosofis dalam lampiran I Undang-Undang Republik Indonesia Nomor 12 Tahun 2011 tentang Pembentukan Peraturan Perundang-Undangan (UU No. 12-2011) termaktub bahwa "pertimbangan atau alasan yang menggambarkan bahwa peraturan yang dibentuk mempertimbangkan pandangan hidup, kesadaran, dan cita hukum yang meliputi suasana kebatinan serta falsafah bangsa Indonesia yang bersumber dari Pancasila dan Pembukaan Undang-Undang Dasar Negara Republik Indonesia Tahun 1945”. Penulis tetap berpandangan bahwa landasan filosofis haruslah memiliki satu hal karena ia bersifat mendasar. Landasan filosofis melingkup landasan sosiologis dan landasan yuridisnya. Diperhatikan lagi pada konsiderans bahwa pencemaran udara disebabkan beberapa hal yaitu emisi gas buang sekaligus mewujudkan perilaku sadar lingkungan. Frasa demikian, menimbulkan penafsiran ganda karena penyebab satu hal diselesaikan dengan penyebab lainnya.

\section{B. Pembahasan}

Di dalam Pasal 2 Perwali Surabaya No. 1-2017 termaktub bahwa:

(1) Pada waktu dan jalan-jalan tertentu di wilayah Kota Surabaya diselenggarakan kegiatan Hari Bebas Kendaraan Bermotor.

(2) Lokasi dan waktu penyelenggaraan kegiatan Hari Bebas Kendaraan Bermotor ditetapkan sebagai berikut:

a. Jalan Raya Darmo (mulai persimpangan Jalan Raya Darmo - Jalan Dr. Soetomo - Jalan Polisi Istimewa sampai dengan persimpangan Jalan Raya Darmo - Jalan Diponegoro) pada hari minggu mulai pukul 06.00 WIB sampai dengan pukul 09.30 WIB;

b. Jalan Tunjungan (mulai persimpangan Jalan Tunjungan - Jalan Praban - Jalan Gemblongan - Jalan Genteng Kali sampai dengan perbatasan Jalan Tunjungan - Jalan Gubernur Suryo) pada hari minggu mulai pukul 06.00 WIB sampai dengan pukul 09.00 WIB;

c. Jalan Kertajaya (mulai persimpangan Jalan Dharmawangsa - Jalan Kertajaya sampai dengan persimpangan Jalan Kertajaya - Jalan Menur) setiap hari minggu, pada minggu ketiga setiap bulan mulai pukul 06.00 WIB sampai dengan pukul 09.00 WIB;

d. Jalan Sedap Malam (mulai persimpangan Jalan Walikota Mustajab - Jalan Sedap Malam sampai dengan persimpangan Jalan Jimerto - Jalan Sedap Malam) dan Jalan Jimerto (mulai persimpangan Jalan Jimerto - Jalan Wijaya Kusuma sampai dengan

${ }^{3}$ Sebelumnya berlaku:

Peraturan Walikota Surabaya Nomor 74 Tahun 2013 tentang Penyelenggaraan Hari Bebas Kendaraan Bermotor (Perwali No. 74-2013) dan Peraturan Walikota Surabaya Nomor 24 Tahun 2014 tentang Perubahan Atas Peraturan Walikota Surabaya Nomor 74 Tahun 2013 Tentang Penyelenggaraan Hari Bebas Kendaraan Bermotor (Perwali Surabaya No. 24-2014). 
persimpangan Jalan Jaksa Agung Suprapto - Jalan Jimerto) setiap hari jum'at, pada minggu terakhir setiap bulan mulai pukul 06.00 WIB sampai dengan pukul 13.00 WIB;

e. Jalan Jemur Andayani (mulai persimpangan Jalan Raya Jemursari - Jalan Jemur Andayani sampai dengan persimpangan Jalan Jemur Andayani - Jalan Raya Kendangsari) setiap hari minggu, pada minggu pertama setiap bulan mulai pukul 06.00 WIB sampai dengan pukul 09.00 WIB;

f. Jalan Kembang Jepun (mulai persimpangan Jalan Kembang Jepun - Jalan Kalimati Kulon sampai dengan persimpangan Jalan Kembang Jepun - Jalan Dukuh) setiap hari minggu, pada minggu kedua setiap bulan mulai pukul 06.00 WIB sampai dengan pukul 09.00 WIB;

g. Jalan Dr. Ir. H. Soekarno (mulai persimpangan Jalan Kertajaya Indah - Jalan Dr. Ir. H. Soekarno sampai dengan persimpangan Jalan Arif Rahman Hakim - Jalan Dr. Ir. H. Soekarno) setiap hari minggu, pada minggu keempat setiap bulan mulai pukul 06.00 WIB sampai dengan pukul 09.00 WIB.

(3) Dalam hal penyelenggaraan kegiatan Hari Bebas Kendaraan Bermotor sebagaimana dimaksud pada ayat (2) bertepatan dengan bulan suci ramadhan, maka waktu pelaksanaannya ditetapkan sebagai berikut:

a. Jalan Raya Darmo sebagaimana dimaksud pada ayat (2) huruf a dilaksanakan pada hari minggu mulai pukul 06.00 WIB sampai dengan 09.00 WIB;

b. Jalan Tunjungan sebagaimana dimaksud pada ayat (2) huruf b dilaksanakan pada hari minggu mulai pukul 06.00 WIB sampai dengan 08.30 WIB;

c. Jalan Kertajaya sebagaimana dimaksud pada ayat (2) huruf c dilaksanakan setiap hari minggu, pada minggu ketiga setiap bulan mulai pukul 06.00 WIB sampai dengan 08.30 WIB;

d. Jalan Sedap Malam dan Jalan Jimerto sebagaimana dimaksud pada ayat (2) huruf d dilaksanakan setiap hari jum'at, pada minggu terakhir setiap bulan mulai pukul 06.00 WIB sampai dengan 11.00 WIB;

e. Jalan Jemur Andayani sebagaimana dimaksud pada ayat (2) huruf e dilaksanakan setiap hari minggu, pada minggu pertama setiap bulan mulai pukul $06.00 \mathrm{WIB}$ sampai dengan 08.30 WIB;

f. Jalan Kembang Jepun sebagaimana dimaksud pada ayat (2) huruf f dilaksanakan setiap hari minggu, pada minggu kedua setiap bulan mulai pukul 06.00 WIB sampai dengan 08.30 WIB;

g. Jalan Dr. Ir. H. Soekarno sebagaimana dimaksud pada ayat (2) huruf g dilaksanakan setiap hari minggu, pada minggu keempat setiap bulan mulai pukul 06.00 WIB sampai dengan 08.30 WIB.

(4) Ketentuan terkait lokasi dan waktu penyelenggaraan kegiatan Hari Bebas Kendaraan Bermotor sebagaimana dimaksud pada ayat (2), tidak berlaku pada saat hari besar keagamaan.

(5) Setiap orang yang mengendarai kendaraan bermotor dilarang melintasi jalan sebagaimana dimaksud pada ayat (2), pada waktu penyelenggaraan kegiatan Hari Bebas Kendaraan Bermotor, kecuali ditentukan lain berdasarkan peraturan perundangundangan.

(6) Penyelenggaraan kegiatan Hari Bebas Kendaraan Bermotor harus didukung dengan: 
a. ketersediaan petugas pengamanan;

b. adanya jalur pengalihan alternatif;

c. ketersediaan sarana dan prasarana.

Dari Pasal 2 Perwali Surabaya No. 1-2017 tersebut, diketahui bahwa jalan yang termaktub dalam ayat (2) tidak berlaku pada saat hari besar keagamaan dan pada ayat (4) melarang setiap orang yang mengendarai kendaraan bermotor untuk melintasi jalan pada ayat (2). Pertentangan lainnya pada ayat (3) dimana pada saat bulan suci ramadhan terjadi perubahan jam. ${ }^{4}$ Mengacu pada ayat (6) bahwa penyelenggaraan Hari Bebas Kendaraan Bermotor didukung dengan ketersediaan petugas pengamanan; adanya jalur pengalihan alternatif; dan ketersediaan sarana dan prasarana.

Dengan tidak memberlakukan Perwali Surabaya No. 1-2017 pada hari besar keagamaan maka hal ini menunjukkan bahwa peraturan perundang-undangan ini sebetulnya dapat dikompromikan pelaksanaannya. Dari sini, penelusuran teleologi ${ }^{5}$ hukum menjadi sangat vital karena hanya mencari tujuan akhir dari suatu peraturan perundang-undangan. Teleologi berbeda dengan tujuan dalam pasal suatu peraturan perundang-undangan karena tujuan dalam pasal merupakan tujuan umum dibentuknya peraturan perundang-undangan tersebut dan apabila disatukannya tujuan-tujuan tersebut akan tercipta teleologi hukum. Tujuan yang bersifat umum hanya berlaku dalam tempat dan ruang waktu tertentu. Tujuan ini dapat membias ketika fakta hukum berubah-ubah. Di dalam hal ini, penyelenggaraan hari bebas kendaraan bermotor memiliki tujuan yang baik antara lain: ${ }^{6}$

1. Mengurangi dan mengendalikan pencemaran udara di wilayah Kota Surabaya;

2. Membentuk kebiasaan bagi masyarakat untuk giat berolahraga;

3. Memunculkan rasa kebersamaan di dalam Kota Surabaya;

${ }^{4}$ Perwali No. 74-2013 dan Perwali Surabaya No. 24-2014 hanya mencantumkan frasa "hari besar keagamaan".

${ }^{5}$ Teleologi dapat dijelaskan sebagai:

a. Studi tentang gejala-gejala yang memperlihatkan keteraturan, rancangan, tujuan, akhir, maksud, kecenderungan, sasaran, arah, dan bagaimana hal-hal ini dicapai dalam suatu proses perkembangan. Studi ini mencapai doktrin bahwa tujuan, sebab final, atau maksud harus diketengahkan sebagai prinsip-prinsip penjelasan.

b. Teleologi merupakan ajaran filosofis-religius tentang eksistensi tujuan-tujuan dan "kebijaksanaan" objektif di luar manusia. Ia terungkap dalam antrofomorfisme idealistik dari objek-objek dan prosesproses alamiah. Ia mengaitkan hal-hal itu dengan tindakan prinsip-prinsip penetapan-sasaran untuk melaksanakan tujuan-tujuan yang ditentukan sebelumnya. Tesis ini mengandaikan adanya seorang pencipta yang adiintelijen dan mendasari bukti teleologis dari adanya Allah.

c. Menurut teleologi transendental-antroposentrik, prinsip penetapan-sasaran, atau Allah, yang berada di luar dunia, memperkenalkan tujuan-tujuan dalam alam yang diciptakan bagi manusia. Menurut teleologi imanen, setiap objek dalam alam dalam dirinya sendiri mempunyai suatu tujuan vital yang intrinsik, suatu sebab yang mempunyai tujuan. Tujuan vital atau sebab yang bertujuan itu merupakan sumber gerakan dari bentuk-bentuk yang lebih tinggi.

d. Dengan bermacam-macam bentuk, teleologi, terdapat dalam stoisisme, Neoplatonisme, dalam konsepsi harmoni yang ditetapkan sebelumnya, dalam teori "jiwa-dunia" dari Schelling, dalam idealisme objektif Hegel, neo-Kantianisme, neo-Thomisme, personalisme, dan sebagainya, lebih lanjut dalam Tomy Michael, Konstelasi Teori Dalam Ilmu Hukum, 2015, Surabaya, R.A.De.Rozarie, h. 8-9.

${ }^{6}$ Baik dalam Perwali Surabaya No. 1-2017, Perwali No. 74-2013 dan Perwali Surabaya No. 24-2014 tidak ditemukan tujuan spesifik dari adanya perwali tersebut. Penulis memberikan tujuan tersebut berdasarkan pengalaman empiris selama tinggal di Kota Surabaya. 
4. Menjadikan Kota Surabaya sebagai daya tarik wisata melalui kegiatan seni di sepanjang lokasi hari bebas kendaraan bermotor; dan

5. Meningkatkan perekonomian di Kota Surabaya;

Mengurangi dan mengendalikan pencemaran udara di wilayah Kota Surabaya sebetulnya telah dilakukan dengan baik di Surabaya karena banyaknya ruang hijau. Sifat pengurangan dan pengendalian ini tidak tepat karena Hari Bebas Kendaraan Bermotor lingkupnya kecil. Pencemaran udara tidak hanya bersumber dari kendaraan berotor melainkan banyak faktor seperti banyaknya pedagang makanan yang menghasilkan polusi udara seperti sate ataupun belum baik penegakan hukum terhadap peraturan derah larangan merokok.

Membentuk kebiasaan bagi masyarakat untuk berolahraga ketika dibenturkan dengan Pasal 5 huruf e Undang-Undang Republik Indonesia Nomor 3 Tahun 2005 tentang Sistem Keolahragaan Nasional (UU No. 3-2005) termaktub bahwa:

Keolahragaan diselenggarakan dengan prinsip:

a. Demokratis, tidak diskriminatif dan menjunjung tinggi nilai keagamaan, nilai budaya, dan kemajemukan bangsa;

b. Keadilan sosial dan nilai kemanusiaan yang beradab;

c. Sportivitas dan menjunjung tinggi nilai etika dan estetika;

d. Pembudayaan dan keterbukaan;

e. Pengembangan kebiasaan hidup sehat dan aktif bagi masyarakat;

f. Pemberdayaan peran serta masyarakat;

g. Keselamatan dan keamanan; dan

h. Keutuhan jasmani dan rohani.

Membentuk kebiasaan bagi masyarakat untuk berolahraga ini juga hanya sebatas dimana Hari Bebas Kendaraan Bermotor ini diberlakukan, masyarakat yang berada di daerah sekitarnya memiliki tingkat kesehatan dibandingkan dengan masyarakat yang tempatnya berjauhan seperti di Jalan Bratang Gede, Jalan Ikan Buntek, Jalan Arjuna, Jalan Ikan Sumbal atau Jalan Tanjung Sadari. Perbedaan ini disatu sisi sesuai dengan Pasal 5 huruf e UU No. 3-2005.

Memunculkan rasa kebersamaan di dalam Kota Surabaya betul-betul tercermin dalam Hari Bebas Kendaraan Bermotor karena didalamnya masyarakat berbaur menjadi satu menciptakan suatu kegiatan. Kegiatan yang dimaksud antara lain berolahraga bersama, pertunjukan seni, menmapilkan kesadaran untuk mencintai hewan-hewan langka, ajang permainan tradisional yang terkait dengan kebudayaan. Rasa kebersamaan yang berada dalam masyarakat tidak sekadar menyerahkan alienasi kepada pemerintah kota Surabaya tetapi menjadikan alienasi tersebut itu terberi dalam masyarakat dan memiliki siklus tersendiri. Kebersamaan ini menciptakan suatu utilitarian tersendiri karena dalam kelompok kecil menyebar pada masyarakat luas.

Menjadikan Kota Surabaya sebagai daya tarik wisata melalui kegiatan seni di sepanjang lokasi hari bebas kendaraan bermotor. Mengacu Pasal 4 Undang-Undang Republik Indonesia Nomor 5 Tahun 2017 tentang Pemajuan Kebudayaan (UU No. 5-2017) termaktub bahwa:

Pemajuan Kebudayaan bertujuan untuk:
a. mengembangkan nilai-nilai luhur budaya bangsa;
b. memperkaya keberagaman budaya;
c. memperteguh jati diri bangsa; 
d. memperteguh persatuan dan kesatuan bangsa;

e. mencerdaskan kehidupan bangsa;

f. meningkatkan citra bangsa;

g. mewujudkan masyarakat madani;

h. meningkatkan kesejahteraan rakyat;

i. melestarikan warisan budaya bangsa; dan

j. mempengaruhi arah perkembangan peradaban dunia, sehingga Kebudayaan menjadi haluan pembangunan nasional.

Daya tarik wisata yang termaktub dalam Perwali Surabaya No. 1-2017 merupakan peningkatan pendapatan Kota Surabaya. Tentu saja, Perwali Surabaya No. 1-2017 adalah sarana pariwisata yang banyak memberikan edukasi kepada masyarakat di sepanjang lokasi hari bebas kendaraan bermotor.

Meningkatkan perekonomian di Kota Surabaya sudah berlaku secara otomatis ketika didalamnya terdapat kegaiatn yang terkait daya Tarik masyarakat luas. Daya tarik tersebut bisa juga melalui adanya bangunan yang menarik, adanya acara rutin bulanan seperti pertunjukan wayang ataupun kegiatan tahunan seperti pelaksanaan hari-hari nasional tertentu. Perekonomian yang ditingkatkan tersebut akan membawa dampak positif bagi masyarakat dan pemerintah kota. Kedua subjek hukum ini melakukan sinergitas untuk mencapai perekonomian yang dimaksud.

Tetapi beberapa tujuan yang baik tersebut sebetulnya tidak sejalan dengan teleologi hukum Perwali Surabaya No. 1-2017. Mengurangi dan mengendalikan pencemaran udara di wilayah Kota Surabaya dengan mengadakan hari bebas kendaraan bermotor tidak selaras dengan tujuan hukum yaitu keadilan hukum.

Keadilan hukum tidak dapat berlaku secara kaku. Keadilan hukum akan selalu berubah ketika negara menerapkan kebijakan berbeda dalam menjalankan pemerintahannya. Keadilan hukum mengacu pada filsuf alam hanya berupa ide semata oleh karena itu keadilan hukum yang bersifat abstrak itu dapat ditelaah lebih lanjut. Keadilan hukum merupakan tujuan secara khusus dalam peraturan perundang-undangan yang merupakan bagian dari teleologi hukum.

Hari bebas kendaraan bermotor di jalan seperti yang termaktub dalam Pasal 2 ayat (2) huruf a sampai huruf g Perwali Surabaya No. 1-2017 merupakan ketidakmampuan Pemerintah Kota Surabaya dalam memahami hakikat "Mengurangi dan mengendalikan pencemaran udara di wilayah Kota Surabaya", yang penulis maksud yaitu ketika masyarakat akan menuju ke Pasar Genteng Surabaya melalui Jalan Tunjungan maka ia akan melakukan perjalanan dengan waktu tempuh yang lebih lama dan lebih jauh. Begitu juga ketika akan menuju Jalan Undaan dari Jalan Tegalsari mengalami perputaran jalan yang jauh. Ketika banyak terjadi perpindahan jalur ini maka pencemaran udara ini akan bertambah banyak. Hal ini menimbulkan pencemaran udara di luar lokasi hari bebas kendaraan bermotor mengalami perpindahan emisi gas buang ke lokasi lainnya.

Mengacu ayat (6) bahwa penyelenggaraan Hari bebas Kendaraan Bermotor didukung dengan ketersediaan petugas pengamanan; adanya jalur pengalihan alternatif; dan ketersediaan sarana dan prasarana. Saat ini ketersediaan petugas pengamanan tetap menjadi prioritas utama karena seluruh petugas keamanan dikerahkan dalam menjaga hari bebas kendaraan bermotor. Syarat kedua yaitu adanya jalur pengalihan alternatif belum tersedia secara baik. Jalur pengalihan alternatif masih tetap menggunakan jalur pada umumnya ketika 
tidak dilaksanakannya hari bebas kendaraan bermotor. Jalur pengalihan alternatif yang dikehendaki dalam Perwali Surabaya No. 1-2017 adalah jalur yang digunakan pada saat hari bebas kendaraan bermotor saja. Jalur pengalihan alternatif bukanlah jalur pada umumnya yang digunakan dengan membagi penggunaan jalur.

Jalur pengalihan alternatif hingga saat ini upaya memindahkan titik kemacetan kepada titik lainnya sehingga hari bebas kendaraan bermotor tetap berlangsung tanpa memperkirakan kemacetan kendaraan bermotor yang terjadi.7 Penulis mengutip pemikiran Lefebvre's (1991) conceptualization of the triad moments of social space is fruitful to elaborate the concept of spatial turn. Lefebvre (1991) argues that there is a dialectic between the notion of 'spatial practice', 'representation of space', and 'representational space' which characterized our society today. The notion of 'representation of space' is the space conceptualized by city planners, urbanists, and technocrats, which entails places where our daily lives are performed $(1991, p .38)$. In other words, this is the space constructed by social actors who have the formal authority to govern, which simultaneously is the space where our day to day social practices are occurring. Arguably, this law of 'representations of space' is conceived by the municipal and provinvial governments seeking to produce order in the city (Lefebvre, 1991, p. 33). The law deployed rely legality therefore focusing solely on the violation or criminality dimensions without interrogating the complex emotional ties, attachments, or symbols that may exist between everuyday practices and the living space. In other words, the notion of 'representation of space' is often utilized to categorize and regulates which practices are allowed or create disorder.On the other hand, study needs to approach social movement also through the notion of 'representational space' which appreciates that everyday practices which produce its own conception of a space. This notion of 'representational space' encompasses the day to day practices of the actors and the living space, where space is associated with images and symbols, revealing how a particular place is felt to be important for certain group, "Space as directly lived through its associated images and symbols ... It overlays physical space, making symbolic use of its objects" (1991, p. 39). In other words, 'representational space' is the space which is constituted not only through tangible materials but also meanings, memories, utopias, dreams, and so on (Sack, 1997).Arguably, the dialectic between the spatial practices, the representational space, and the space of representation will lead to a comprehensive investigation on what people actually do in that space, and how they conceptualise their own relationships to that space (Anjaria, 2006, p. 2140). Besides the triadic moments above, Harvey have proposed a triple layers of contestation which enrinch the notion of spatial turn. Similar to how Lefebvre

${ }^{7}$ Pelaksanaan Kegiatan Hari Bebas kendaraan Bermotor pada Pasal 3 Perwali Surabaya No. 1-2017

(1) Penyelenggaraan kegiatan hari bebas kendaraan bermotor di Kota Surabaya dilaksanakan oleh Pelaksana Hari Bebas Kendaraan Bermotor yang terdiri atas perangkat daerah terkait, antara lain:

a. Dinas Lingkungan Hidup;

b. Badan Penanggulangan Bencana Dan Perlindungan Masyarakat;

c. Dinas Perhubungan;

d. Dinas Kebersihan dan Ruang Terbuka Hijau;

e. Dinas Komunikasi Dan Informatika;

f. Bagian Hubungan Masyarakat;

g. Satuan Polisi Pamong Praja;

h. Kecamatan;

i. Kelurahan.

(2) Dalam rangka Penyelenggaraan kegiatan hari bebas kendaraan bermotor di Kota Surabaya, Pelaksana Hari Bebas Kendaraan Bermotor dapat melibatkan instansi terkait.

(3) Guna kelancaran pelaksanaan kegiatan Hari Bebas Kendaraan Bermotor, Walikota dapat membentuk Tim Pelaksana Kegiatan Hari Bebas Kendaraan Bermotor. 
distinguishes between the notion of 'representational space', 'spatial practices', and the 'space of representation',Harvey argues that there are the notions of 'absolute space', 'relative space', and relational space (2006). The first two notions, absolute space and relative space, Harvey are the dominant perspectives which imagines every social process can be quantified and therefore banishing all uncertainties and ambiguities (2006). This is problematic because "Processes do not occur in space but define their own spatial frame" (Harvey, 2006). Through our daily practices, our actions do not only occur in a space, but also construct its own perceptions of space and place. In turn, this spatial frame influence or alter our daily practices. Harvey calls this notion 'relational space'. Harvey's notion on space relationality brings further implications. First, space can no longer be conceived as given and fixed. Instead, space is an object of transformation: its limits can be redrawn, its rules reformulated, its power structure altered, and its members rearranged. This transformation, moreover, is inherently political. Dominant discourse in a space attempt to regulate and normalize people daily conduct while people organize daily resistance, invest new meanings and imaginations to their space, or even appropriate dominating rules and discourses for their purposes (de Carteau, 1984). Lefebvre's dialectic of representations of space, representational space, and spatial practice is helpful in elucidating this process. Second, space functions not only as a container of spatial practices. Space determines the form of spatial practices that emerge within it. Its scale-its limit and scope-shape people practices, memberships, institutions, and politics. Space's regime of representations also determines what is considered to be proper conduct inside a certain space (Elden, 2001; Foucault, 1991). However, since space itself is always an object of politics - thus, reinventions, redrawings, reformulations - different spaces are possible to be exist at the same moment (Marston, 2000). This condition brings interesting implication: a body is living in different spaces with their different regimes of representations simultaneously. A body is thus being regulated by different logics of appropriateness and required to response - or resist - all these normalizing power at the same time (Harvey, 2000). This competing and, perhaps, contradicting visions of proper performations are internalized to citizens body. This condition gives rise to a specific form of citizenship that contains all those contradictions-including fundamentalist groups' form of citizenship (Harvey, 1996). ${ }^{8}$

\section{Penutup}

Kesimpulan yang diperoleh dalam Perwali Surabaya No. 1-2017 tidak memiliki teleologi hukum terkait keadilan hukum. Eksistensi Perwali Surabaya No. 1-2017 hanya memberikan manfaat bagi sebagian kecil masyarakat tanpa memperhatikan kebutuhan masyarakat lainnya. Ketika Perwali Surabaya No. 1-2017 dibenturkan dengan hakikat hari

\footnotetext{
${ }^{8}$ Lebih lanjut dalam Dana Hasibuan dan Rizky Alif Alvian, Citizenship and the Politics of Space in Indonesia: Reflections on the Politics of Pluralism in Yogyakarta, 2016, Yogyakarta, Universitas Gadjah Mada, h. 2-4. Alasan penulis mengutip secara utuh untuk memahami hakikat masyarakat dalam lingkup ilmuilmu humaniora. Masyarakat tidak dapat dipahami secara sederhana tanpa adanya kajian mendalam dan ilmu hukum khususnya sosiologi hukum tidak memiliki landasan kuat dalam mengkaji masyarakat seperti yang dikehendaki dalam Perwali Surabaya No. 24-2014. Penulis juga mengandaikan pemikiran Benedict Anderson bahwa "Tak ragu lagi yang paling aneh adalah kisah saat Amangkurat II wafat pada 1703 seperti dituturkan dengan khidmat dalam babad-babad. Amangkurat II adalah seorang raja Jawa akhir abad ke-17 yang kurang berhasil dan belum menunjuk pewaris takhta. Saat para calon dan abdi mengelilingi ranjangnya, salah seorang dari mereka, Pangeran Puger, melihat bahwa penis sang raja yang wafat itu berdiri keras dan di ujungnya ada setetes cairan berkilau. Ia buruburu meminum cairan itu, lalu penis itu pun melunak. Penulis babad menambahkan bahwa ini berarti wahyu keraton telah diturunkan ke pangeran, yang menjadi Amangkurat III.", lebih lanjut dalam Benedict Anderson, Hidup Di Luar Tempurung, 2016, Tangerang Selatang, Marjin Kiri, h. 113-114.
} 
besar keagamaan maka Pemerintah Kota Surabaya memberikan siapapun untuk merayakannya, mengingat juga di Pasal 2 ayat (2) Perwali Surabaya No. 1-2017 terdapat berbagai tempat untuk mendekatkan diri pada Yang Esa yaitu Makam Sunan Bungkul, Gereja Katolik Hati Kudus Yesus, Rumah Suci Bodhimandala Genteng Sayangan, atau Gereja Bethel Tabernakel Pniel. Saran yang dapat diambil yaitu ketika ada peraturan perundang-undangan terkait hari bebas kendaraan bermotor maka alternatif jalan harus mendapat perhatian utama agar paradigma hukum benar-benar tercipta yang membawa konsekuensi bahwa peraturan perundang-undangan tersebut berjalan optimal.

\section{DAFTAR PUSTAKA}

Benedict Anderson, Hidup Di Luar Tempurung, 2016, Tangerang Selatang, Marjin Kiri.

Dana Hasibuan dan Rizky Alif Alvian, Citizenship and the Politics of Space in Indonesia: Reflections on the Politics of Pluralism in Yogyakarta, 2016, Yogyakarta, Universitas Gadjah Mada. H R Otje Salman dan Anthon F Susanto, Teori Hukum, 2013, Bandung, Refika Aditama.

John Tondowidjojo, Hadiah Terbesar Umat Manusia, Tahun II/Edisi 21/XII-2016 Surabaya, Gereja Katolik Kristus Raja.

Tomy Michael, Konstelasi Teori Dalam Ilmu Hukum, 2015, Surabaya, R.A.De.Rozarie. 